Testing Rent Sharing Using Individualized Measures of Rent: Evidence from Domestic Helpers

\author{
Wing Suen*
}

RRH: SUEN: RENT SHARING IN THE DOMESTIC HELPERS MARKET 


\title{
Testing Rent Sharing Using Individualized Measures of Rent: Evidence from Domestic Helpers
}

\begin{abstract}
The market for resident domestic helpers offers a rare opportunity where the surplus from employment relationship can be quantitatively measured for each individual employee. Using the difference between employer's cost of time and employee's wage as a measure of rent, it is found that wages for domestic helpers are positively related to rent. However the apparent sharing of rent is better explained by matching than by efficiency wage models. Rent sharing is observed even in households where monitoring or turnover costs are low. Rent sharing is not observed among newly arrived foreign domestic helpers, whose ability remains to be revealed.
\end{abstract}

Wing Suen

The University of Hong Kong

Hong Kong 
This paper studies the pattern of wages for resident domestic helpers in Hong Kong. No one has the right to lure economists into paying attention to this arcane labor market were it not for one feature of the market for housework: A measure of employment rent can be plausibly assigned to each individual employee. Having an individualized measure of rent at the worker level (instead of a general measure at the firm level) will shed considerable light on the large and growing literature of rent sharing in wage determination.

Since 1975 the Hong Kong government has allowed the importation of foreign domestic helpers into the territory. Because of large wage differences between Hong Kong and some of its Asian neighbors, the program is highly popular. The Census and Statistics Department [1995] estimates that 92,700 households, or $5.6 \%$ of all domestic households in Hong Kong, employed domestic helpers in 1993. The figure is even more dramatic for high income households: $44 \%$ of households with monthly income of over HK $\$ 50,000$ had one or more domestic helpers. ${ }^{1}$

One consequence of the availability of market-procured housework is that women who employ helpers have more time for market work. In Suen [1994], I estimate that the probability of labor force participation among married women who had domestic helpers is 22 percentage points higher than that for women without domestic help, other things equal. If hiring a helper enables a married woman to engage in market work, then a plausible measure for the "rent" or surplus from this employment relationship is the difference between the woman's wage and her helper's wage. If a woman with a domestic helper decides to stay home nonetheless, the size of the surplus can be measured by the difference between the shadow value of leisure and the helper's wage. Wage information is readily available from census data, and shadow wages can be estimated using standard techniques. This paper utilizes this rare opportunity to impute a measure of rent for each employer-employee pair. Studying how the wages of domestic helpers vary with the magnitude of rent will provide direct evidence for rent sharing in the labor market.

There is a large literature which documents the fact that the characteristics of the employer, such as industry affiliation and firm size, are significantly correlated with the 
employees' wages. Krueger and Summers [1988], Brown and Medoff [1989], Groshen [1991], Helwege [1992], and many other studies offer convincing evidence that interindustry wage differentials and employer wage effects exist. Rent sharing is often invoked to account for such wage patterns. However, few studies in the literature offer a plausible account for the existence of or a measure for the size of the "rent" that is supposedly shared. ${ }^{2}$ At the industry level, Dickens and Katz [1987] use variables such as concentration ratio, capital-labor ratio, research and development expenditures, and average rate of return on capital as covariates in wage equations. These variables provide at best an indirect and error-prone measure of employment rent. Campbell's [1993] study makes use of firm level characteristics instead of industry characteristics, but there is no information on profits in his firm level data. Similarly, Groshen and Krueger [1990], Krueger [1991], and Rebitzer and Taylor [1995] focus on wage policies within particular industries. None of these studies contains any explicit measure of rent. This large body of literature provides convincing evidence against a competitive model of wage determination with no sorting on unobserved ability, but it is not directly relevant for resolving the hypothesis that employers share their surplus with workers.

Even if firm level data on profits are available, there are conceptual problems in using total firm profits as the measure of employment rent for all employees of the firm. In a Nash [1950] bargaining model of rent sharing, for example, the division of rent depends on threat points, and threat points are unlikely to be the same for an airplane pilot and for a reservation clerk in the same airline, say. Similarly, in Akerlof's [1982] gift exchange model, producers do not simply give away part their profits to employees as charity. The size of the "gifts" to be exchanged will depend on the importance of the job and on the potential for shirking. The ideal measure of employment rent should therefore be specific to each employee; a general measure of rent that pertains only to the employer would not be sufficient for evaluating how the employer shares rent with her many different employees. Fortunately a distinctive feature of the market for domestic helpers is that an employer usually hires only one employee. This market therefore offers a possibly unique opportunity where employee-specific measures of rent can be constructed. 
Note that the concept of "rent" used in this study refers to employers' rent, and is different from the concept of appropriable rent as in Klein, Crawford, and Alchian [1978]. I do not suggest that employers are held hostage by their employees so that the full employment surplus is subject to negotiation. Since there is a market for domestic helpers, the "appropriable" part of the employment surplus is only a fraction of the difference between employers' wage and employees' wage. Nevertheless, in the empirical literature on inter-industry wage differentials, rent sharing is effectively taken to refer to the positive correlation between employers' rent and wages, regardless of whether such rent is appropriable by employees or not. The most common approach to test rent sharing in the labor market is to enter various proxies for employers' ability to pay in a reduced form wage equation. ${ }^{3}$ Employees' ability to capture rent (such as union status) is not a crucial aspect of these studies. Most studies find that more profitable employers tend to pay higher wages, even if there is no institutional impediments to replace their existing workers with cheaper ones. The gift exchange model or some kind of fair wage consideration as in Akerlof and Yellen [1990] is usually used to justify why employers willingly share their rent with employees. The measure of rent adopted in this paper is consistent with the empirical rent sharing literature.

Section I of this paper begins with a brief description of the data used in the analysis. Then, in Section II, I show that the wage of a domestic helper is higher, the higher the wage of the female head of household. Assuming the surplus from the employment relationship is the difference between the female employer's wage and the domestic helper's wage, this finding is consistent with the rent sharing hypothesis. Section III extends this finding to families whose female heads are not in the labor force. I use a standard selection model to impute the reservation wages for the female employers. Again the wage of a domestic helper is found to be positively correlated with the reservation wage of her female employer.

What seems to be rent sharing can potentially be explained by efficiency wage models or by competitive models with sorting on unobserved quality. Section IV of this paper argues that the relationship between employer's wage and employee's wage cannot be 
reconciled with efficiency wage models. I assume there are systematic differences in monitoring costs between employers who work and employers who do not work, and that there are systematic differences in turnover costs between households with young children and households without young children. I find that employers with high wages (or high reservation wages) still pay their helpers more even when monitoring costs or turnover costs are relatively low. This observation is inconsistent with efficiency wage models.

In Section $\mathrm{V}$ the employer wage effect in the market for domestics is analyzed in the context of a matching model. McLaughlin [1994] describes a model of efficient matching in thin markets which may give rise to employer wage effects, and Murphy and Topel [1990] offer empirical evidence which suggests that sorting by observed characteristics is significant across industries. In the market for domestic helpers, if high wage employers desire to hire better domestic helpers (a positive income elasticity of demand for quality), and if some dimensions of the helper's ability are unobserved by the econometrician, there will be a positive relationship between employer's wage and employee's wage. In Hong Kong most domestic helpers have come from foreign countries with no prior experience in the trade. Among domestic helpers who newly arrived in Hong Kong, therefore, there is little information available for matching. Consistent with the matching model, rent sharing is not observed for this group of domestics.

\section{DATA DESCRIPTION}

Data for the analysis come from the five percent random sample file of the 1991 Hong Kong Population Census. Because the Hong Kong government requires employers of foreign domestic helpers to provide them with accommodation, most domestic helpers reside in the same household with their employers. This allows easy identification of employer-employee pairs in the census data. I select for analysis all individuals aged 15 to 64 whose relationship to the household head is coded "resident domestic helper (including private chauffeur or gardener)." Of these 2,860 individuals, 98 percent are female. Since men are more likely to work as chauffeurs or gardeners than as domestic helpers, they are excluded from the subsequent analysis. This paper requires information 
about the employers as well as the domestic helpers. Therefore, only those records with both the household head and his/her spouse present are used. Finally a few records where the domestic helper shows no earnings are excluded. The resulting sample consists of 2,184 observations. ${ }^{4}$

Table I shows selected descriptive statistics on the sample of domestic helpers and their employers. The most noteworthy aspect of this market is that $98 \%$ of the domestic helpers were not permanent residents of Hong Kong. Of these foreign helpers, $92 \%$ were from the Philippines. These domestic helpers had very limited labor market experience in Hong Kong. Only six percent had resided in Hong Kong for ten years or more, and the average duration of residence in Hong Kong for the remaining group was 2.6 years. About $20 \%$ of them could speak the local Cantonese dialect.

[Table I about here]

The census records do not have information about work hours, and wages are measured by reported monthly income from main employment. Since the sample only contains live-in domestics, it can safely be presumed that they all worked full time. In Hong Kong most full time domestics are paid a monthly salary, so the monthly income figure is a good measure of the wage rate. The average monthly wage of a domestic helper was $\$ 2,922$, which was slightly less than half the wage of an average woman in Hong Kong. Although the nature of domestic work is quite homogeneous, there is a fair amount of dispersion in wages. The standard deviation of wages was $\$ 499$, with a range from $\$ 700$ to $\$ 17,000 .^{5}$

The households employing domestic helpers on average had four family members. Sixty percent of the female heads reported positive earnings. Among households without helpers, the comparable figure was $38 \%$. This indicates that by hiring domestic helpers to do the housework, married women will have more time to engage in market work. ${ }^{6}$ Not only are married women more likely to work if they have domestic helpers, they also tend to earn higher wages. The average wage of wives in households with domestic helpers was $\$ 15,832$; wives in households without domestics earned $\$ 3,250$.

The majority of the households in the sample (94\%) hire only one helper, and the 
sample contains 1,999 unique employer-employee pairs. For households that hire more than one helper, the employer variables are duplicated while the employee variables are unique. It may be, however, conceptually less attractive to use the difference between the wife's wage and the domestic helper's wage as a measure of employment rent in such households, because the allocation of work among the many helpers is unclear. In the subsequent analysis, results are presented using observations on all employees. I have also performed the analysis using only observations where employer-employee pairs are unique. The results are virtually the same as the ones reported here.

At the time of the census, employers who hired a foreign domestic helper were required to pay a monthly wage of at least $\$ 2,800$ before the contract would be approved by the Labour Department. However, this minimum wage requirement was hardly enforced. Figure 1 shows the distribution of the wages reported by domestic helpers in the census (outliers are not shown in the figure). Although the figure shows a spike of observations with a wage of $\$ 2,800$, about $23 \%$ of the domestic helpers reported receiving less than the minimum wage and $46 \%$ reported receiving more than the minimum wage. I know of no instance where an employer was prosecuted for violating the minimum wage provision.

[Figure 1 about here]

\section{DO HIGH WAGE EMPLOYERS PAY HIGH WAGES?}

In a competitive model with no sorting on unobserved ability, the wage of an employee is independent of the identity of her employer. Rent sharing models do not have this independence property. However the mere finding that employees' wages depend on the characteristics of their employers constitutes little support for the rent sharing hypothesis, unless these characteristics are systematically related to the magnitude of the employment surplus. In this section I use a direct measure of employment surplus based on the female employer's market wage, and analyze how this measure of rent is related to the employee's wage. This section only focuses on households where the wives work so that direct observations on market wages are available. The next section deals with the case where the wife does not participate in the labor market. 
Consider a simple Nash bargaining model where the employee's utility function is $u(\cdot)$ and the employer's utility function is $v(\cdot)$. Both utility functions are assumed to be weakly concave. Let $W_{i}$ be the wage that domestic helper $i$ receives from her employer, and let $\bar{W}_{i}$ be her alternative wage. If the employment relationship continues, the domestic helper will take care of the housework and her female employer can engage in market work at wage $Y_{i}$. The employer's utility level is $v\left(Y_{i}-W_{i}\right)$. If the relationship terminates, the wife would either have to stop working or she would have to consume less leisure. For working individuals, the value of leisure is equal to the market wage $Y_{i}$ at the margin. Therefore $v\left(Y_{i}-W_{i}\right)-v(0)$ represents the wife's surplus, regardless of whether she will continue to work or not when she does not have a helper,

Let $\gamma$ represent the relative bargaining strength of the domestic helper. Then the Nash bargaining solution will solve:

$$
\max _{W_{i}} \quad\left[u\left(W_{i}\right)-u\left(\bar{W}_{i}\right)\right]^{\gamma}\left[v\left(Y_{i}-W_{i}\right)-v(0)\right] .
$$

The first-order condition to this problem satisfies:

$$
\gamma u^{\prime}\left(W_{i}\right)\left[v\left(Y_{i}-W_{i}\right)-v(0)\right]-v^{\prime}\left(Y_{i}-W_{i}\right)\left[u\left(W_{i}\right)-u\left(\bar{W}_{i}\right)\right]=0
$$

Let $W_{i}=f\left(\bar{W}_{i}, Y_{i}\right)$ be the implicit solution to the above equation. It can be shown that $f_{1}>0$ and $f_{2}>0$. Alternatively, one can define $R_{i}=Y_{i}-W_{i}$ to be a measure of rent. Then equation (2) can be solved for $W_{i}$ in terms of $\bar{W}_{i}$ and $R_{i}$. This implicit solution can be written as $W_{i}=g\left(\bar{W}_{i}, R_{i}\right)$, with $g_{1}>0$ and $g_{2}>0$. The dependence of $W_{i}$ on the rent variable $Y_{i}$ or $R_{i}$ will provide direct evidence for rent sharing in the market for domestics. ${ }^{7}$

The purpose of this bargaining model is to illustrate one reason why employers with greater surplus may pay higher wages to employees. Obviously, there are other models (such as efficiency wage models) that will deliver a similar result. Moreover a full analysis of the bargaining problem would require greater attention to search and turnover costs. To the extent that turnover costs are not zero, a fraction of the surplus $R_{i}$ will be subject to bargaining and the preceding analysis will apply minor modifications. Even in a perfectly competitive market, where the alternative to not hiring a certain 
domestic helper is to hire another helper in the market, there may be non-competitive reasons (such as gift exchange or fair wage) for the employer to share the surplus with her domestic helper. Indeed, the empirical literature on inter-industry wage differentials tends to emphasize these reasons. The extent to which rent sharing is significant in the market for domestic helpers is a matter to be determined empirically.

In the empirical analysis, I assume that the domestic helper's alternative wage depends on her personal characteristics and on the characteristics of her job. These personal characteristics include education, potential experience, marital status, whether the person is a permanent local resident, and her duration of stay in Hong Kong. The job characteristics include house_size, children and elderly (see Table I for variable description). Large household size may indicate more work for the domestic helper and jobs in such households may command a compensating differential. Similarly, the presence of young children or elderly persons in the household may make work for a domestic helper more or less desirable, and hence affect wages.

Column (1) of Table II shows the log wage regression for domestic helpers without using rent variables. In this particular labor market, education and potential experience have insignificant effects (statistically and economically) on wages. Most of the workers in the sample received their schooling in the Philippines, which may be of limited relevance for their job as a domestic helper in Hong Kong. Similarly many of these workers worked in a different occupation before they came to Hong Kong, and their prior experience may have limited effect on earnings. Local experience, on the other hand, turns out to be highly significant. For those who have resided in Hong Kong for less than ten years, each additional year of residence is accompanied by a one percent increase in earnings. Permanent residents of Hong Kong also earn 15\% higher wages than imported foreign domestic helpers. Among the job characteristics variables, only the number of elderly persons in the household has a statistically significant negative effect (at the 0.05 level) on wages. One interpretation is that elderly people can help out in the domestic chores and make work less burdensome for the maids. The overall goodness-of-fit of the wage regression is modest: Variations in personal and job characteristics account for less 
than seven percent of the variations in log wages.

[Table II about here]

The remaining four columns of Table II investigate the effect of rent variables on wages. Column (2) shows that high wage employers pay higher wages to their helpers. This relationship remains in column (3), which controls for personal and job characteristics. The elasticity of employee's wage with respect to employer's wage is 0.024 . This elasticity may seem "small," but variations in employers' wages are much greater than variations in the wages for domestic helpers. According to the estimate, a domestic helper whose employer's log wage is one standard deviation above the mean would earn a log wage which is 0.13 standard deviation above the average domestic helper. ${ }^{8}$ Notice, however, that introducing employer's wage into the wage regression only increases the $R^{2}$ by about 0.016 . A substantial dispersion in wages remains. ${ }^{9}$

In columns (4) and (5) of Table II, I use $\log R$ instead of $\log Y$ as the measure of rent. Since $R$ is defined as $Y-W$, it will be correlated with the regression error. The estimates are obtained by instrumental variables regressions, with $\log Y$ as the instrument for $\log R$. The coefficient on $\log R$ is 0.027 , and is statistically significant at the 0.01 level. These results indicate that wages of domestic helpers are positively correlated with direct measures of employment rent.

\section{NON-WORKING EMPLOYERS}

In the sample of domestic helpers, $40 \%$ have female employers who do not participate in the labor force. For these employers, hiring servants helps relieve the burden of housework and allows more time for leisure. Let $Y^{\prime}$ represent the value of leisure. Then the non-working employer's surplus from the employment relationship is $v\left(Y^{\prime}-W\right)-v(0)$. Rent variables can be constructed by using $Y^{\prime}$ or by using $R^{\prime}=Y^{\prime}-W$. Although the value of leisure is not directly observable, the value of leisure at zero hours of work (the reservation wage) can be estimated using standard techniques. This section proposes to use the imputed reservation wage as a proxy for rent. 
Let the reservation wage and the market wage for employer $i$ be, respectively:

$$
\begin{aligned}
& \log Y_{i}^{\prime}=X_{1 i} \beta_{1}+u_{1 i} ; \\
& \log Y_{i}=X_{2 i} \beta_{2}+u_{2 i},
\end{aligned}
$$

where $X_{1}$ and $X_{2}$ refer to the characteristics of the employer, $\beta_{1}$ and $\beta_{2}$ are the corresponding vectors of coefficients, and the disturbance terms $u_{1}$ and $u_{2}$ are jointly normal. Define an index variable $I_{i}=\log Y_{i}-\log Y_{i}^{\prime}$. Then

$$
I_{i}=Z_{i} \delta+e_{i}
$$

where $Z$ is the union of the $X_{1}$ and $X_{2}$ variables, $\delta$ is the coefficient vector conformable to $Z$, and $e=u_{1}-u_{2}$. For labor force participants, $I_{i}>0$ and $Y_{i}$ can be observed. For non-working women, $I_{i} \leq 0$ and $Y_{i}$ is not observed. The parameters $\beta_{2}$ and $\delta$ in equations (4) and (5) can be estimated using a standard Heckman [1976] sample selection model.

The maximum likelihood estimates of equations (4) and (5) are presented in Table III. Most of the variables are highly significant and have the expected signs. Two points are worth mentioning, however. First, in contrast to usual labor supply models, the presence of young children in the family does not reduce the probability of labor force participation. Suen [1994] argues that this is because women in this sample all have domestic helpers to take care of their children; the finding does not extend to Hong Kong women in general. Second, as Lam and Liu [1995] point out, a married woman who lives with her parents or parents-in-law can often receive help from her (usually retired) parents in performing household chores. Thus the presence of elderly persons in the household is found to significantly increase the probability of labor participation.

[Table III about here]

Using the estimated coefficients in Table III, the reservation wage for a non-working employer (i.e., the predicted value of $\log Y_{i}^{\prime}$ ) can be obtained by:

$$
\hat{y}_{i}^{\prime}=X_{2 i} \hat{\beta}_{2}-Z_{i} \hat{\delta}-\sigma_{1 e}\left[\phi\left(-Z_{i} \hat{\delta}\right) / \Phi\left(-Z_{i} \hat{\delta}\right)\right]
$$

where $\sigma_{1 e}$ is the covariance between $u_{1}$ and $e .{ }^{10}$ The last term in equation (6) is the 
correction for selectivity bias. The variable $\hat{y}^{\prime}$ is used to measure rent for the sample of domestic helpers who work for non-working employers.

Table IV presents log wage regressions for domestic helpers with non-working employers. Since the rent variable $\hat{y}^{\prime}$ is estimated from an auxiliary model, OLS standard errors are wrong. The standard errors shown in the table are derived from Murphy and Topel's [1985] method of calculating asymptotically correct standard errors in two-step models. The results of the regressions are quite similar to those obtained from the sample of domestic helpers with working employers shown in Table II. Column (1) of Table IV indicates that employers with higher reservation wages tend to pay significantly higher wages to their domestic helpers. In column (2), an alternative measure of employment rent is defined:

$$
\hat{r}^{\prime}=\log \left(\exp \left(\hat{y}^{\prime}\right)-W\right)
$$

Again, since $\hat{r}^{\prime}$ is correlated with the regression error, the equation is estimated using instrumental variables regression, with $\hat{y}^{\prime}$ as the instrument for $\hat{r}^{\prime}$. The conclusion remains unchanged. Wages of the domestic helpers are positively related to either measure of employment rent.

[Table IV about here]

\section{MONITORING AND TURNOVER COSTS}

What explains the observed relationship between employer's wage (or reservation wage) and employee's wage? It is insufficient to invoke "rent sharing" as the explanation for the phenomenon: the explanation is the observation. In order to understand why employers seem to share rent with their employees, more detailed models of wage determination are required. This section discusses two versions of efficiency wage models - the monitoring model and the turnover model - and analyzes their relevance to the market for domestic helpers. ${ }^{11}$

In the monitoring models of Eaton and White [1983] and Shapiro and Stiglitz [1984], employers pay their employees more than the competitive wage to reduce supervision costs and to deter shirking or theft. If high time cost employers have more to lose 
from non-performance on the part of their domestic helpers, they are expected to pay their helpers higher wages. Note, however, that this relationship obtains only if direct supervision is costly.

It is not difficult to imagine that employers who stay at home face a much lower cost in monitoring their domestic helpers than do employers who participate in market work. If this is the case, rent sharing between employers and their helpers should be much less pronounced in the sample of non-working employers than in the sample of working employers. The evidence in the previous section, however, fails to confirm this prediction. The coefficient on the rent variable is positive and significant even in the non-working employers sample.

More formally, the monitoring model can be tested by introducing an interaction term between rent and monitoring costs in the wage regression for domestic helpers. I assume monitoring costs are relatively high when the wife engages in market work (wife_work $=1$ ). Rent is measured by the opportunity cost of time:

$$
\log V= \begin{cases}\log Y, & \text { if } Y>0 \\ \hat{y}^{\prime}, & \text { otherwise }\end{cases}
$$

where the imputed value of time $\hat{y}^{\prime}$ is given by (6).

In Table V, column (1), the coefficient on the dummy variable for the wife's employment status (wife_work) is statistically indistinguishable from zero. Thus, although working employers face a higher cost of supervising their domestic helpers, they do not pay a wage premium. ${ }^{12}$ Moreover the interaction between monitoring costs and rent is negative and statistically insignificant. Contrary to the prediction of the monitoring model, the degree of rent sharing does not increase when monitoring costs are high, as when the female employer have to work and cannot directly supervise her helper.

[Table $\mathrm{V}$ about here]

It is also possible that elderly parents or parents-in-law present in the household may help monitor the domestic helper. Monitoring costs are therefore particularly likely to be high if both the employer works and there is no elderly person in the household. In column (2) of Table $\mathrm{V}$, the rent variable is interacted with wife_work $\times$ no_elderly. 
The monitoring hypothesis would predict that the coefficient on this interaction term is positive, but the data does not support such a prediction.

Another possible explanation for the observed relationship between rent and wages is Salop's [1979] turnover model of efficiency wages. According to this model employers pay their employees above-competitive wages in order to discourage labor quits. If high time cost employers have more incentive to reduce labor turnover, they will pay their domestic helpers higher wages. The extent of this rent sharing will depend on, among other things, the costs of disruptions caused by domestic helpers quitting their job. In families with young children, especially if the wife works, it is reasonable to assume that the disruptions will be more substantial. The turnover model can therefore be tested by introducing an interaction term between rent and the number of young children in the wage regression for domestic helpers.

Column (1) of Table VI shows the regression estimates using the full sample of domestic helpers. The number of children in the household does not significantly increase the wage of a domestic helper. Moreover families with more children do not share a greater proportion of the employment rent with their helpers: The coefficient on the interaction term is negative and statistically insignificant. This conclusion remains unchanged if the sample is restricted to families where the wife works (column 2) or to families where the wife stays home (column 3). The evidence therefore does not support the turnover model of rent sharing, which predicts that rent sharing should be more pronounced in households where the wife works and where young children have to be taken care of. ${ }^{13}$

[Table VI about here]

\section{UNOBSERVED ABILITY AND MATCHING}

The apparent sharing of rent need not reflect efficiency wages; a competing hypothesis is sorting on unobserved worker ability. Recently McLaughlin [1994] has proposed a model of rent sharing that is consistent with labor market efficiency. He argues that when worker quality is heterogeneous and employer-employee matching is important, 
labor markets are naturally thin. In such markets the wage of a worker will depend on the identity of her employer for two reasons. First, different employers will hire workers with systematically different abilities for efficient matching. Second, there is room for bargaining over rent within the efficient match. Rent sharing in this model are not associated with involuntary unemployment.

In the market for domestic helpers, worker qualities such as obedience, courtesy, dependability, and devotion to children are unobservable to the econometrician but are at least partly observable by employers. If high wage employers demand domestic helpers with high ability, then efficient sorting on unmeasured ability may explain the correlation between the wife's wage and the domestic helper's wage.

There are at least two reasons why high wage employers may demand better domestic helpers. Both reasons are related to the fact that high wage employers tend to have high income. First, the quality of a domestic helper and market goods may be complementary inputs in the production of domestic services. As in Kremer's [1993] O-ring production function, for example, a wealthy family is willing to pay to a premium for a careful domestic helpers lest she would break the expensive furnitures and antiques. Second, the quality of a domestic helper may simply be a normal good. These two explanations are not mutually exclusive, and it is difficult to distinguish between them with the available data.

The matching hypothesis requires that employers know the ability of their employees, though such ability may be unobservable to the econometrician. For domestic helpers who have been in Hong Kong for a number of years, this assumption is reasonable. Direct observation of work behavior and referrals from former employers can provide good information about worker ability. Efficient matching is facilitated by the frequent turnover of domestic helpers. ${ }^{14}$ For domestic workers who have just arrived in Hong Kong, on the other hand, information about their ability is much more limited. Many employers hire their domestics from overseas through specialized employment agencies. These agencies may perform some initial screening, but because of the nature of the job, formal qualifications such as education are of limited value in predicting work ability. 
Attributes which are important in this trade cannot be revealed without a period of close supervision. Moreover, since most foreign domestic helpers worked in other occupations before they came to Hong Kong, past experience may not be a good indicator of their ability as a domestic helper. The matching hypothesis then predicts that employer's wage will have little or no effect on the wages of newly arrived foreign domestic workers.

I divide the sample of domestic helpers into two groups: those who have lived in Hong Kong for not more than one year, and those who have been in Hong Kong for over one year. Because of employers' lack of information about the ability of the former group of workers, matching is expected to be relatively unimportant. If the relationship between the wife's wage and the helper's wage is a result of sorting on unobserved ability, such relationship should be weaker among the newly arrived helpers than in the other group. Table VII shows the regression results. The coefficient on $\log V$ in the group who have lived in Hong Kong for more than one year (column 2) is 0.032 and is significant at the 0.01 level. In contrast the coefficient on $\log V$ in the newly arrived group (column 1) is 0.012 and is statistically insignificant at the 0.05 level. Therefore, when employers do not have the opportunity to observe worker ability, there is no evidence of rent sharing. ${ }^{15}$

[Table VII about here]

Another piece of evidence that corroborates the matching hypothesis is that the domestic helper's wage seems to be positively correlated with the husband's wage as well as with the wife's wage. In $89 \%$ of the households in the sample, the husband's wage is greater than the wife's wage. In the absence of a domestic helper, it is expected that the wife would have to shoulder the bulk of the household chores because of different time costs. As the husband will concentrate on market work with or without a domestic helper, his market wage is a poor measure of employment surplus. Therefore if bargaining over the employment surplus is the main reason behind the positive correlation between wife's wage and employee's wage, the correlation should be much weaker between husband's wage and employee's wage. On the other hand, if the positive correlation is driven by matching between high income households and high ability domestic helpers, both the husband's wage and the wife's wage should be correlated with their 
maid's pay.

I have estimated a log wage regression for domestic helpers that includes, besides personal and job characteristics, both the time cost of the wife $(\log V)$ and the wage of the husband ( $\log ($ husband_wage)) as independent variables. The coefficient on $\log V$ is $0.016(t=2.97)$, and coefficient on $\log$ (husband_wage) is $0.024(t=5.83) .{ }^{16}$ The hypothesis that these two coefficients are equal cannot be rejected. There is no evidence that husband's wage has a smaller impact than wife's wage on the pay of their domestic helper. Instead the evidence suggest apparent rent sharing is the result of a positive income elasticity for (unobserved) quality.

If high income households prefer to hire helpers with greater unobserved ability, it seems plausible that they prefer to hire helpers with greater observed ability as well. Evidence to the contrary would then cast doubt on the matching hypothesis. Murphy and Topel [1990] indeed find that industries which pay higher wages tend to employ workers with more desirable observable characteristics. In the market for domestic helpers, one observable characteristic that proves to be an important indicator of labor quality is the duration of residence in Hong Kong. The variables duration_0-9 and duration_10 (see Table I for definition) are consistently found to have positive and significant effects on the wage of domestic helpers. I therefore regress these two quality variables on the wages of the employers. Table VIII displays the results. Column (1) shows clearly that high wage employers are more likely to hire domestic helpers with more local experience. Similarly column (2) suggests that high wage employers are more likely to be matched with domestics who have ten or more years of residence in the territory.

\section{[Table VIII about here]}

To obtain a more comprehensive measure of observable ability, I estimate a wage regression on three sets of variables: the personal characteristics of the domestic helper $\left(C_{1}\right)$, the characteristics of her job $\left(C_{2}\right)$, and the wages (or reservation wages) of the male and female heads of household $\left(C_{3}\right)$. Denote the corresponding vector of estimated coefficients by $\hat{\alpha}_{1}, \hat{\alpha}_{2}$ and $\hat{\alpha}_{3}$. Then the linear combination $C_{1} \hat{\alpha}_{1}$ can be considered as an index of the domestic helper's observable ability. This index is used as the dependent 
variable in the regression shown in column (3) of Table VIII. The result again indicates that high ability helpers are more likely to be associated with high wage employers.

\section{CONCLUSION}

Although the market for resident domestic helpers is a relatively special segment of the labor market, it provides a unique opportunity for researchers to investigate rent sharing models of wage determination. Because the employer of a resident domestic helper can easily be identified in census records, direct measurement of employment surplus can be obtained using information about the employer's wage or reservation wage. This paper shows that the employee's wage is clearly positively related to such measures of employment rent.

The reason behind the observed relationship between rent and wages, however, is less obvious. Monitoring and turnover models do not seem to explain the observed relationship, as wages are found to be positively related to rent even when monitoring costs or turnover costs are low. The matching hypothesis, on the other hand, is not rejected by the data. Among newly arrived foreign domestic helpers, whose ability remains largely unknown to employers, there is no evidence of rent sharing, as predicted by the matching model. There is also some evidence that high wage employers tend to hire employees with higher observed ability. What seems to be rent sharing in this market is therefore not inconsistent with competitive wage determination when heterogeneity in unobserved worker quality is taken into account.

Unlike most labor markets, the output of domestic helpers (housework) are not sold to consumers. Instead the employer consumes the output herself. The scale of the "firm" in this market is also much smaller than firms in other markets: each employer typically hires only one worker. It is hard to determine to what extent the conclusions from the market for domestic helpers will carry over to other labor markets. For example, the income effect on the demand for worker quality is probably not a concern for profit making firms. On the other hand, Kremer's [1993] production complementarities model implies that firms with high quality inputs will also demand high quality workers, 
so matching is still an important consideration in these labor markets away from the household. Every labor market has its own idiosyncrasies. If rent sharing is supposed to be a general model of wage determination, the evidence presented in this paper cannot be lightly dismissed. 


\section{REFERENCES}

Akerlof, George A. "Labor Contracts as Partial Gift Exchange." Quarterly Journal of Economics, November 1982, 543-569.

—, and Janet L. Yellen. "The Fair Wage-Effort Hypothesis and Unemployment." Quarterly Journal of Economics, May 1990, 255-283.

Bell, Linda A., and Richard B. Freeman. "The Causes of Increasing Interindustry Wage Dispersion in the United States." Industrial and Labor Relations Review, January $1991,275-287$.

Blanchflower, David G., Andrew J. Oswald, and Peter Sanfey. "Wages, Profits, and Rent-Sharing." Quarterly Journal of Economics, February 1996, 227-251.

Brown, Charles, and James Medoff. "The Employer Size Wage Effect." Journal of Political Economy, October 1989, 1027-1059.

Campbell, Carl M., III. "Do Firms Pay Efficiency Wages? Evidence with Data at the Firm Level." Journal of Labor Economics, July 1993, 442-470.

Census and Statistics Department. Social Data Collected by the General Household Survey: Special Topics Report No. 11. Hong Kong: Government Printer, 1995.

Dickens, William, and Lawrence Katz. "Inter-Industry Wage Differences and Industry Characteristics," in Unemployment and the Structure of Labor Markets, edited by K. Lang and J. Leonard. New York: Basil Blackwell, 1987, 48-89.

Eaton, Curtis, and William D. White. "The Economy of High Wages: An Agency Problem." Economica, May 1983, 175-181.

Groshen, Erica L. "Sources of Intra-Industry Wage Dispersion: How Much Do Employers Matter?" Quarterly Journal of Economics, August 1991, 869-910.

— , and Alan B. Krueger. "The Structure of Supervision and Pay in Hospitals." Industrial and Labor Relations Review, February 1990, S134-S146. 
Heckman, James J. "The Common Structure of Statistical Models of Truncation, Sample Selection, and Limited Dependent Variables and a Simple Estimator for Such Models." The Annals of Economic and Social Measurement, 5, 1976, 475-492.

Helwege, Jean. "Sectoral Shifts and Interindustry Wage Differentials." Journal of Labor Economics, January 1992, 55-84.

Klein, Benjamin, Robert G. Crawford, and Armen A. Alchian. "Vertical Integration, Appropriable Rents, and the Competitive Contracting Process." Journal of Law and Economics, October 1978, 297-326.

Kremer, Michael. "The O-Ring Theory of Economic Development." Quarterly Journal of Economics, August 1993, 551-575.

Krueger, Alan, and Lawrence Summers. "Inter-Industry Wage Differentials." Econometrica, March 1988, 259-293.

Lam, Kit Chun, and Pak Wai Liu. "Non-Working Parents and Labor Force Participation of Married Women with Children." Working paper, Hong Kong Baptist University, 1995.

McLaughlin, Kenneth J. "Rent Sharing in an Equilibrium Model of Matching and Turnover." Journal of Labor Economics, October 1994, 499-523.

Murphy, Kevin M., and Robert H. Topel. "Estimation and Inference in Two-Step Econometric Models." Journal of Business and Economic Statistics, October 1985, 370379.

—. "Efficiency Wages Reconsidered: Theory and Evidence," in Advances in the Theory and Measurement of Unemployment, edited by Y. Weiss and G. Fishelson. London: MacMillan, 1990, 204-240.

Nash, John F. "The Bargaining Problem." Econometrica, April 1950, 155-162. 
Rebitzer, James B., and Lowell J. Taylor. "Efficiency Wages and Employment Rents: The Employer-Size Wage Effect in the Job Market for Lawyers." Journal of Labor Economics, October 1995, 678-708.

Rose, Nancy L. "Labor Rent Sharing and Regulation: Evidence from the Trucking Industry." Journal of Political Economy, December 1987, 1146-1178.

Salop, Steven C. "A Model of the Natural Rate of Unemployment." American Economic Review, March 1979, 117-125.

Shapiro, Carl, and Joseph E. Stiglitz. "Equilibrium Unemployment as a Worker Discipline Device." American Economic Review, June 1984, 433-444.

Suen, Wing. "Market-Procured Housework: The Demand for Domestic Servants and Female Labor Supply.” Labour Economics, September 1994, 289-302.

Taylor, John B. "Aggregate Demand Dynamics and Staggered Contracts." Journal of Political Economy, February 1980, 1-24.

Van Reenen, John. "The Creation and Capture of Rents: Wages and Innovation in a Panel of U.K. Companies." Quarterly Journal of Economics, February 1996, 195226. 


\section{NOTES}

* I am indebted to Doug Allen, Yoram Barzel, Steven Cheung, Curtis Eaton, Alan Siu and Junsen Zhang for their comments. Mrs. Doris Bote Chung, manager of a local employment agency, provided me with valuable information about the market for domestic helpers.

Suen: Senior Lecturer, School of Economics and Finance, The University of Hong Kong, Hong Kong, Phone 852-2859-1052, Fax 852-2859-1152, E-mail hrneswc@hkusua.hku.hk

1 The value of the Hong Kong dollar is pegged at the exchange rate of one U.S. dollar to 7.8 Hong Kong dollars.

2 A notable exception is Rose [1987]. She uses the deregulation of the trucking industry as a natural experiment to study how a reduction in industry rent affect labor earnings.

3 Examples of such proxies include per capita profitability (Blanchflower, Oswald, and Sanfey [1996]), productivity growth (Bell and Freeman [1991]), market power in the product market (Dickens and Katz [1987]), and rate of technical innovation (Van Reenen [1996]).

${ }^{4}$ Because of the way domestic helpers are identified in the census records, domestics who worked part time or who did not live with their employers are not included. According to a Census and Statistics Department [1995] survey conducted in 1993, 85\% of all domestics were live-in helpers.

5 Another source of wage variation is differences in unmeasured in-kind amenities. For live-in helpers, the most significant components of such amenities are food and shelter. Because there are economies of scale in the preparation of food and because there is a public good aspect to shelter within the household, in-kind amenities are probably better in more wealthy families than in less wealthy ones. Introducing inkind benefits is therefore likely to reinforce any positive relationship between employers' income and employees' pay. 
6 The causation can also be reversed: working women are more likely to hire domestics than non-working women. See Suen [1994] for a more detailed analysis.

${ }^{7}$ Using the wife-servant wage difference as a measure of rent abstracts from the direct utility or disutility from housework. To the extent that the wife derives direct utility from housework (e.g., spending time with children), the wage difference overestimates the surplus from hiring a helper. To the extent that the wife prefers pursuing market work to performing household chores, the wage difference underestimates the surplus from hiring a helper.

${ }^{8}$ I have also estimated regression (3) in linear form instead of double-log form. The coefficient of $Y$ on $W$ is 0.0047 (s.e. $=0.0008)$. Thus a one standard deviation $(\$ 12,888)$ increase in the employer wage is accompanied by a 0.12 standard deviation (\$61) increase in the maid's pay.

9 The previous section indicates that the distribution of dependent variable has a spike at the legal minimum wage (for foreign domestic helpers) of $\$ 2,800$. To test the robustness of the results, I recoded the wages of domestic helpers into three categories: below minimum wage, at minimum wage, and above minimum wage. This recoded wage variable is then used as the dependent variable in an ordered probit model. The estimated coefficient on $\log Y$ remains positive and statistically significant.

${ }^{10}$ Since $u_{1}=u_{2}-e$, we have $\sigma_{1 e}=\sigma_{2 e}-\sigma_{e}^{2}=0.2788 \times 0.6863-1=-0.8087$.

11 Another variant of efficiency wage models is the Akerlof [1982] gift exchange model. I fail to derive any testable implications from that model.

12 It is reasonable to assume that women who stay at home will spend more time doing housework than women who work. Domestic helpers are then likely to have more household duties if the wife participates in market work, and their job will command a positive compensating differential. Compensating differences therefore cannot explain the absence of a wage premium.

13 The evidence is also inconsistent with Klein, Crawford, and Alchian's [1978] model of appropriable rent, which suggests that families with young children may be held up 
by the resident domestic helper.

14 There are many small employment agencies in Hong Kong specializing in helping employers to find domestic helpers in Hong Kong. Notice boards in local supermarkets are filled with advertisements by domestic helpers trying to find new jobs.

15 In the sample of newly arrived helpers, the duration_0-9 variable is either 0 or 1 year. The negative coefficient on duration_0-9 in column (1) of Table VII shows that persons who had arrived in Hong Kong for less than one year received higher wages than those who arrived a year earlier. This is a clear indication of Taylor's [1980] staggered wage setting effect, for employers in Hong Kong are required to sign a two year contract with newly arrived foreign domestic helpers.

${ }^{16}$ In another regression I restrict the sample to households where both the husband and the wife report positive earnings. The results are essentially the same. The coefficient on $\log$ (wife_wage) is 0.015 and that on $\log$ (husband_wage) is 0.026 . 
TABLE I

Selected Descriptive Sample Statistics

\begin{tabular}{|c|c|c|c|}
\hline Variable & Description & Mean & (s.d.) \\
\hline \multicolumn{4}{|c|}{ Characteristics of domestic helpers: } \\
\hline age & Age & 32.47 & $(8.20)$ \\
\hline education & Years of education & 11.48 & $(3.57)$ \\
\hline experience & Potential experience & 14.40 & $(8.82)$ \\
\hline married & Dummy variable for married helper & 0.37 & $(0.48)$ \\
\hline local & Has right of abode in Hong Kong & 0.02 & $(0.15)$ \\
\hline duration_10 & Resided in Hong Kong for at least 10 years & 0.06 & $(0.24)$ \\
\hline duration_0-9 & Years of residence in Hong Kong $(\max .=9)^{a}$ & 2.64 & $(2.46)$ \\
\hline cantonese & Can speak Cantonese & 0.20 & $(0.40)$ \\
\hline wage & Monthly earnings & 2922 & $(499)$ \\
\hline \multicolumn{4}{|c|}{ Characteristics of employers: } \\
\hline house_size & Household size (excl. domestic helpers) & 3.95 & $(1.16)$ \\
\hline children & Number of children aged below 6 & 0.75 & $(0.77)$ \\
\hline elderly & Number of persons aged 65 or above & 0.21 & $(0.53)$ \\
\hline no_elderly & No elderly person in the household & 0.85 & $(0.36)$ \\
\hline wife_work & Female employer reports positive employment earnings & 0.60 & $(0.49)$ \\
\hline wife_wage & Wife's monthly employment earnings ${ }^{b}$ & 15832 & $(12888)$ \\
\hline wife_age & Wife's age & 38.53 & $(9.44)$ \\
\hline wife_education & Wife's years of schooling & 12.06 & $(3.29)$ \\
\hline wife_hongkong & Wife was born in Hong Kong & 0.59 & $(0.49)$ \\
\hline wife_english & Wife can speak English & 0.86 & $(0.35)$ \\
\hline husband_work & Male employer reports positive employment earnings & 0.93 & $(0.26)$ \\
\hline husband_wage & Husband's monthly employment earnings ${ }^{c}$ & 31728 & $(25732)$ \\
\hline
\end{tabular}

All earnings figures are in 1991 Hong Kong Dollars. Unless otherwise stated, the sample consists of 2184 domestic helpers and 1999 distinct households employing one or more helpers.

${ }^{a}$ Based on 2048 observations.

${ }^{b}$ Based on 1198 observations.

${ }^{c}$ Based on 1857 observations. 
TABLE II

Log Wage Regression for Domestic Helpers:

Working Employers Sample

\begin{tabular}{|c|c|c|c|c|c|}
\hline Variable & (1) & $\begin{array}{l}\text { Depend } \\
(2)\end{array}$ & $\begin{array}{l}\text { nt Variable: } \\
(3)\end{array}$ & $\begin{array}{r}\log W \\
(4)\end{array}$ & $(5)$ \\
\hline constant & $\begin{array}{c}7.9106 \\
(0.0261)\end{array}$ & $\begin{array}{c}7.7069 \\
(0.0498)\end{array}$ & $\begin{array}{c}7.6826 \\
(0.0554)\end{array}$ & $\begin{array}{c}7.6715 \\
(0.0401)\end{array}$ & $\begin{array}{c}7.6463 \\
(0.0471)\end{array}$ \\
\hline \multicolumn{6}{|l|}{ rent variables: } \\
\hline $\log Y$ & & $\begin{array}{l}0.0271^{* *} \\
(0.0053)\end{array}$ & $\begin{array}{l}0.0241^{* *} \\
(0.0052)\end{array}$ & & \\
\hline $\log R$ & & & & $\begin{array}{c}0.0315^{* *} \\
(0.0044)\end{array}$ & $\begin{array}{c}0.0273^{* *} \\
(0.0043)\end{array}$ \\
\hline \multicolumn{6}{|c|}{ personal characteristics: } \\
\hline education & $\begin{array}{c}0.0017 \\
(0.0013)\end{array}$ & & $\begin{array}{c}0.0016 \\
(0.0013)\end{array}$ & & $\begin{array}{c}0.0022 \\
(0.0013)\end{array}$ \\
\hline experience & $\begin{array}{c}0.0007 \\
(0.0006)\end{array}$ & & $\begin{array}{c}0.0006 \\
(0.0006)\end{array}$ & & $\begin{array}{c}0.0006 \\
(0.0006)\end{array}$ \\
\hline married & $\begin{array}{l}-0.0002 \\
(0.0086)\end{array}$ & & $\begin{array}{c}0.0006 \\
(0.0086)\end{array}$ & & $\begin{array}{c}0.0006 \\
(0.0084)\end{array}$ \\
\hline local & $\begin{array}{l}0.1507^{* *} \\
(0.0344)\end{array}$ & & $\begin{array}{l}0.1538^{* *} \\
(0.0341)\end{array}$ & & $\begin{array}{l}0.1026^{* *} \\
(0.0349)\end{array}$ \\
\hline cantonese & $\begin{array}{c}0.0067 \\
(0.0102)\end{array}$ & & $\begin{array}{c}0.0104 \\
(0.0102)\end{array}$ & & $\begin{array}{c}0.0123 \\
(0.0100)\end{array}$ \\
\hline duration_10 & $\begin{array}{l}0.0597^{* *} \\
(0.0199)\end{array}$ & & $\begin{array}{l}0.0521^{* *} \\
(0.0198)\end{array}$ & & $\begin{array}{l}0.0657^{* *} \\
(0.0193)\end{array}$ \\
\hline duration_0-9 & $\begin{array}{l}0.0102^{* *} \\
(0.0018)\end{array}$ & & $\begin{array}{l}0.0094^{* *} \\
(0.0018)\end{array}$ & & $\begin{array}{l}0.0090^{* *} \\
(0.0018)\end{array}$ \\
\hline \multicolumn{6}{|c|}{ job characteristics: } \\
\hline house_size & $\begin{array}{l}-0.0011 \\
(0.0043)\end{array}$ & & $\begin{array}{l}-0.0004 \\
(0.0042)\end{array}$ & & $\begin{array}{c}0.0014 \\
(0.0042)\end{array}$ \\
\hline children & $\begin{array}{c}0.0000 \\
(0.0056)\end{array}$ & & $\begin{array}{c}0.0002 \\
(0.0055)\end{array}$ & & $\begin{array}{c}-0.0019 \\
(0.0054)\end{array}$ \\
\hline elderly & $\begin{array}{c}-0.0202^{*} \\
(0.0092)\end{array}$ & & $\begin{array}{c}-0.0204^{*} \\
(0.0091)\end{array}$ & & $\begin{array}{r}-0.0204^{*} \\
(0.0089)\end{array}$ \\
\hline$\hat{\sigma}$ & 0.1380 & 0.1407 & 0.1369 & 0.1359 & 0.1321 \\
\hline$R^{2}$ & 0.0643 & 0.0205 & 0.0801 & 0.0190 & 0.0739 \\
\hline$N$ & 1277 & 1277 & 1277 & 1241 & 1241 \\
\hline
\end{tabular}

Standard errors are shown in parentheses. See Table I for variable definition. Observations with $R \leq 0$ are excluded in equations (4) and (5).

* Coefficient is statistically different from zero at the $5 \%$ level.

** Coefficient is statistically different from zero at the $1 \%$ level. 
TABLE III

Labor Participation and Wage Determination for Female Employers

\begin{tabular}{|c|c|c|}
\hline Variable & $\begin{array}{r}\text { Depen } \\
\text { wife_work }\end{array}$ & $\begin{array}{l}\text { Variables: } \\
\log (\text { wife_wage) }\end{array}$ \\
\hline constant & $\begin{array}{l}-3.5389 \\
(0.6098)\end{array}$ & $\begin{array}{c}5.7803 \\
(0.4530)\end{array}$ \\
\hline wife_education & $\begin{array}{l}0.0867^{* *} \\
(0.0107)\end{array}$ & $\begin{array}{l}0.1042^{* *} \\
(0.0081)\end{array}$ \\
\hline wife_age & $\begin{array}{l}0.1240^{* *} \\
(0.0285)\end{array}$ & $\begin{array}{c}0.0913^{* *} \\
(0.0200)\end{array}$ \\
\hline wife_age ${ }^{2} / 100$ & $\begin{array}{c}-0.1695^{* *} \\
(0.0324)\end{array}$ & $\begin{array}{c}-0.0965^{* *} \\
(0.0235)\end{array}$ \\
\hline wife_hongkong & $\begin{array}{l}0.4243^{* *} \\
(0.0626)\end{array}$ & $\begin{array}{c}0.1631^{* *} \\
(0.0520)\end{array}$ \\
\hline wife_english & $\begin{array}{l}0.1918^{*} \\
(0.0958)\end{array}$ & $\begin{array}{c}0.1386 \\
(0.0710)\end{array}$ \\
\hline $\log$ (husband_wage) & $\begin{array}{c}-0.4709^{* *} \\
(0.0373)\end{array}$ & \\
\hline husband_work & $\begin{array}{l}5.4136^{* *} \\
(0.4004)\end{array}$ & \\
\hline house_size & $\begin{array}{c}-0.1253^{* *} \\
(0.0289)\end{array}$ & \\
\hline children & $\begin{array}{c}0.0131 \\
(0.0472)\end{array}$ & \\
\hline elderly & $\begin{array}{l}0.2431^{* *} \\
(0.0744)\end{array}$ & \\
\hline$\sigma$ & $\begin{array}{l}1 \\
-\end{array}$ & $\begin{array}{c}0.6863 \\
(0.0168)\end{array}$ \\
\hline$\rho$ & \multicolumn{2}{|c|}{$\begin{array}{l}0.2788 \\
(0.1161)\end{array}$} \\
\hline $\log L$ & \multicolumn{2}{|c|}{-2526.58} \\
\hline$N$ & 2184 & 1277 \\
\hline
\end{tabular}

Standard errors are shown in parentheses. See Table I for variable definition.

* Coefficient is statistically different from zero at the $5 \%$ level.

** Coefficient is statistically different from zero at the $1 \%$ level. 
TABLE IV

Log Wage Regression for Domestic Helpers:

Non-Working Employers Sample

\begin{tabular}{|c|c|c|}
\hline Variable & $\begin{array}{l}\text { Dependent } \\
\text { (1) }\end{array}$ & $\begin{array}{c}\log W \\
(2)\end{array}$ \\
\hline constant & $\begin{array}{c}7.5671 \\
(0.1208)\end{array}$ & $\begin{array}{c}7.6251 \\
(0.0985)\end{array}$ \\
\hline \multicolumn{3}{|l|}{ rent variables: } \\
\hline$\hat{y}^{\prime}$ & $\begin{array}{l}0.0368^{* *} \\
(0.0122)\end{array}$ & \\
\hline$\hat{r}^{\prime}$ & & $\begin{array}{l}0.0315^{* *} \\
(0.0101)\end{array}$ \\
\hline \multicolumn{3}{|c|}{ personal characteristics: } \\
\hline education & $\begin{array}{c}0.0008 \\
(0.0014)\end{array}$ & $\begin{array}{c}0.0008 \\
(0.0014)\end{array}$ \\
\hline experience & $\begin{array}{c}0.0009 \\
(0.0007)\end{array}$ & $\begin{array}{c}0.0009 \\
(0.0007)\end{array}$ \\
\hline married & $\begin{array}{c}0.0066 \\
(0.0098)\end{array}$ & $\begin{array}{c}0.0067 \\
(0.0098)\end{array}$ \\
\hline local & $\begin{array}{c}0.0365 \\
(0.0330)\end{array}$ & $\begin{array}{c}0.0367 \\
(0.0330)\end{array}$ \\
\hline cantonese & $\begin{array}{l}-0.0079 \\
(0.0116)\end{array}$ & $\begin{array}{l}-0.0079 \\
(0.0116)\end{array}$ \\
\hline duration_10 & $\begin{array}{l}0.0491^{*} \\
(0.0231)\end{array}$ & $\begin{array}{l}0.0492^{*} \\
(0.0231)\end{array}$ \\
\hline duration_0-9 & $\begin{array}{l}0.0047^{*} \\
(0.0020)\end{array}$ & $\begin{array}{l}0.0047^{*} \\
(0.0020)\end{array}$ \\
\hline \multicolumn{3}{|c|}{ job characteristics: } \\
\hline house_size & $\begin{array}{c}0.0006 \\
(0.0034)\end{array}$ & $\begin{array}{c}0.0006 \\
(0.0034)\end{array}$ \\
\hline children & $\begin{array}{l}0.0168^{* *} \\
(0.0063)\end{array}$ & $\begin{array}{l}0.0169^{* *} \\
(0.0063)\end{array}$ \\
\hline elderly & $\begin{array}{c}-0.0249^{* *} \\
(0.0078)\end{array}$ & $\begin{array}{c}-0.0247^{* *} \\
(0.0077)\end{array}$ \\
\hline$\hat{\sigma}$ & 0.1338 & 0.1338 \\
\hline$R^{2}$ & 0.0545 & 0.0419 \\
\hline$N$ & 907 & 907 \\
\hline
\end{tabular}

Corrected standard errors are shown in parentheses. See Table I for variable definition.

* Coefficient is statistically different from zero at the $5 \%$ level.

** Coefficient is statistically different from zero at the $1 \%$ level. 


\section{TABLE V}

Log Wage Regression for Domestic Helpers:

The Role of Monitoring Costs

\begin{tabular}{|c|c|c|}
\hline Variable & $\begin{array}{l}\text { Dependent } \\
\text { (1) }\end{array}$ & $\begin{array}{c}\text { ble: } \log W \\
(2)\end{array}$ \\
\hline constant & $\begin{array}{c}7.6433 \\
(0.1151)\end{array}$ & $\begin{array}{c}7.6529 \\
(0.0510)\end{array}$ \\
\hline \multicolumn{3}{|l|}{ rent variables: } \\
\hline $\log V$ & $\begin{array}{c}0.0283^{*} \\
(0.0115)\end{array}$ & $\begin{array}{c}0.0280^{* *} \\
(0.0049)\end{array}$ \\
\hline $\log V \times$ wife_work & $\begin{array}{l}-0.0037 \\
(0.0125)\end{array}$ & \\
\hline $\log V \times$ wife_work $\times$ no_elderly & & $\begin{array}{c}-0.0029 \\
(0.0016)\end{array}$ \\
\hline \multicolumn{3}{|l|}{ personal characteristics: } \\
\hline education & $\begin{array}{c}0.0012 \\
(0.0009)\end{array}$ & $\begin{array}{c}0.0011 \\
(0.0009)\end{array}$ \\
\hline experience & $\begin{array}{c}0.0007 \\
(0.0005)\end{array}$ & $\begin{array}{c}0.0006 \\
(0.0005)\end{array}$ \\
\hline married & $\begin{array}{c}0.0029 \\
(0.0064)\end{array}$ & $\begin{array}{c}0.0036 \\
(0.0064)\end{array}$ \\
\hline local & $\begin{array}{c}0.0886^{* *} \\
(0.0236)\end{array}$ & $\begin{array}{c}0.0933^{* *} \\
(0.0237)\end{array}$ \\
\hline cantonese & $\begin{array}{c}0.0018 \\
(0.0076)\end{array}$ & $\begin{array}{c}0.0018 \\
(0.0076)\end{array}$ \\
\hline duration_10 & $\begin{array}{l}0.0527^{* *} \\
(0.0151)\end{array}$ & $\begin{array}{l}0.0526^{* *} \\
(0.0150)\end{array}$ \\
\hline duration_0-9 & $\begin{array}{l}0.0074^{* *} \\
(0.0014)\end{array}$ & $\begin{array}{l}0.0074^{* *} \\
(0.0013)\end{array}$ \\
\hline job characteristics: & & \\
\hline house_size & $\begin{array}{c}0.0019 \\
(0.0026)\end{array}$ & $\begin{array}{c}0.0010 \\
(0.0026)\end{array}$ \\
\hline children & $\begin{array}{c}0.0064 \\
(0.0041)\end{array}$ & $\begin{array}{c}0.0070 \\
(0.0041)\end{array}$ \\
\hline elderly & $\begin{array}{c}-0.0250^{* *} \\
(0.0058)\end{array}$ & $\begin{array}{c}-0.0313^{* *} \\
(0.0068)\end{array}$ \\
\hline wife_work & $\begin{array}{c}0.0325 \\
(0.1237)\end{array}$ & $\begin{array}{c}0.0205 \\
(0.0150)\end{array}$ \\
\hline$\hat{\sigma}$ & 0.1360 & 0.1359 \\
\hline$R^{2}$ & 0.0638 & 0.0654 \\
\hline$N$ & 2184 & 2184 \\
\hline
\end{tabular}

Corrected standard errors are shown in parentheses. See Table I for variable definition.

* Coefficient is statistically different from zero at the $5 \%$ level.

** Coefficient is statistically different from zero at the $1 \%$ level. 
TABLE VI

Log Wage Regression for Domestic Helpers:

The Role of Turnover Costs

\begin{tabular}{|c|c|c|c|}
\hline Variable & \multicolumn{2}{|c|}{ Dependent Variable: $\log W$} & $W$ \\
\hline constant & $\begin{array}{c}7.6679 \\
(0.0632)\end{array}$ & $\begin{array}{c}7.6372 \\
(0.0714)\end{array}$ & $\begin{array}{c}7.5512 \\
(0.1526)\end{array}$ \\
\hline \multicolumn{4}{|l|}{ rent variables: } \\
\hline $\log V$ & $\begin{array}{c}0.0258^{* *} \\
(0.0061)\end{array}$ & $\begin{array}{c}0.0288^{* *} \\
(0.0070)\end{array}$ & $\begin{array}{c}0.0384^{*} \\
(0.0152)\end{array}$ \\
\hline $\log V \times$ children & $\begin{array}{l}-0.0008 \\
(0.0058)\end{array}$ & $\begin{array}{l}-0.0070 \\
(0.0070)\end{array}$ & $\begin{array}{l}-0.0024 \\
(0.0135)\end{array}$ \\
\hline \multicolumn{4}{|c|}{ personal characteristics: } \\
\hline education & $\begin{array}{c}0.0012 \\
(0.0009)\end{array}$ & $\begin{array}{c}0.0017 \\
(0.0013)\end{array}$ & $\begin{array}{c}0.0008 \\
(0.0014)\end{array}$ \\
\hline experience & $\begin{array}{c}0.0007 \\
(0.0005)\end{array}$ & $\begin{array}{c}0.0006 \\
(0.0006)\end{array}$ & $\begin{array}{c}0.0009 \\
(0.0007)\end{array}$ \\
\hline married & $\begin{array}{c}0.0029 \\
(0.0065)\end{array}$ & $\begin{array}{c}0.0003 \\
(0.0086)\end{array}$ & $\begin{array}{c}0.0065 \\
(0.0098)\end{array}$ \\
\hline local & $\begin{array}{c}0.0886^{* *} \\
(0.0237)\end{array}$ & $\begin{array}{l}0.1529^{* *} \\
(0.0342)\end{array}$ & $\begin{array}{c}0.0362 \\
(0.0331)\end{array}$ \\
\hline cantonese & $\begin{array}{c}0.0017 \\
(0.0076)\end{array}$ & $\begin{array}{c}0.0106 \\
(0.0102)\end{array}$ & $\begin{array}{c}-0.0079 \\
(0.0116)\end{array}$ \\
\hline duration_10 & $\begin{array}{l}0.0528^{* *} \\
(0.0151)\end{array}$ & $\begin{array}{l}0.0513^{* *} \\
(0.0199)\end{array}$ & $\begin{array}{l}0.0489^{*} \\
(0.0232)\end{array}$ \\
\hline duration_0-9 & $\begin{array}{l}0.0074^{* *} \\
(0.0013)\end{array}$ & $\begin{array}{l}0.0094^{* *} \\
(0.0018)\end{array}$ & $\begin{array}{l}0.0047^{*} \\
(0.0020)\end{array}$ \\
\hline \multicolumn{4}{|l|}{ job characteristics: } \\
\hline house_size & $\begin{array}{c}0.0019 \\
(0.0026)\end{array}$ & $\begin{array}{l}-0.0004 \\
(0.0042)\end{array}$ & $\begin{array}{c}0.0007 \\
(0.0035)\end{array}$ \\
\hline children & $\begin{array}{c}0.0144 \\
(0.0564)\end{array}$ & $\begin{array}{c}0.0666 \\
(0.0663)\end{array}$ & $\begin{array}{c}0.0400 \\
(0.1339)\end{array}$ \\
\hline elderly & $\begin{array}{c}-0.0247^{* *} \\
(0.0057)\end{array}$ & $\begin{array}{c}-0.0205^{*} \\
(0.0091)\end{array}$ & $\begin{array}{c}-0.0250^{* *} \\
(0.0078)\end{array}$ \\
\hline wife_work & $\begin{array}{l}-0.0038 \\
(0.0073)\end{array}$ & & \\
\hline$\hat{\sigma}$ & 0.1360 & 0.1369 & 0.1339 \\
\hline$R^{2}$ & 0.0638 & 0.0808 & 0.0545 \\
\hline$N$ & 2184 & 1277 & 907 \\
\hline
\end{tabular}

See Table I for variable definition. Standard errors in equations (1) and (3) are corrected for bias due to imputed regressors. Equation (1) is based on the full sample of domestic helpers. Equation (2) is restricted to families where the wife works, and equation (3) is restricted to families where the wife stays home.

${ }^{*}$ Coefficient is statistically different from zero at the $5 \%$ level.

** Coefficient is statistically different from zero at the $1 \%$ level. 
TABLE VII

Log Wage Regression for Domestic Helpers:

The Role of Sorting

\begin{tabular}{|c|c|c|}
\hline Variable & $\begin{array}{l}\text { Dependent } \\
\text { (1) }\end{array}$ & ble: $\begin{array}{l}\log W \\
(2)\end{array}$ \\
\hline constant & $\begin{array}{c}7.8410 \\
(0.0955)\end{array}$ & $\begin{array}{c}7.5925 \\
(0.0565)\end{array}$ \\
\hline \multicolumn{3}{|l|}{ rent variable: } \\
\hline $\log V$ & $\begin{array}{c}0.0119 \\
(0.0092)\end{array}$ & $\begin{array}{c}0.0317^{* *} \\
(0.0052)\end{array}$ \\
\hline \multicolumn{3}{|c|}{ personal characteristics: } \\
\hline education & $\begin{array}{c}0.0007 \\
(0.0017)\end{array}$ & $\begin{array}{c}0.0017 \\
(0.0011)\end{array}$ \\
\hline experience & $\begin{array}{c}0.0008 \\
(0.0009)\end{array}$ & $\begin{array}{c}0.0006 \\
(0.0005)\end{array}$ \\
\hline married & $\begin{array}{l}-0.0118 \\
(0.0116)\end{array}$ & $\begin{array}{c}0.0108 \\
(0.0075)\end{array}$ \\
\hline local & $\begin{array}{c}0.0155 \\
(0.0758)\end{array}$ & $\begin{array}{l}0.1009^{* *} \\
(0.0240)\end{array}$ \\
\hline cantonese & $\begin{array}{c}-0.0075 \\
(0.0147)\end{array}$ & $\begin{array}{c}0.0054 \\
(0.0086)\end{array}$ \\
\hline duration_10 & & $\begin{array}{l}0.0559^{* *} \\
(0.0162)\end{array}$ \\
\hline duration_0-9 & $\begin{array}{c}-0.0322^{* *} \\
(0.0103)\end{array}$ & $\begin{array}{l}0.0085^{* *} \\
(0.0019)\end{array}$ \\
\hline \multicolumn{3}{|c|}{ job characteristics: } \\
\hline house_size & $\begin{array}{c}0.0032 \\
(0.0050)\end{array}$ & $\begin{array}{c}0.0006 \\
(0.0029)\end{array}$ \\
\hline children & $\begin{array}{l}-0.0009 \\
(0.0071)\end{array}$ & $\begin{array}{l}0.0115^{*} \\
(0.0049)\end{array}$ \\
\hline elderly & $\begin{array}{c}-0.0204 \\
(0.0107)\end{array}$ & $\begin{array}{c}-0.0256^{* *} \\
(0.0064)\end{array}$ \\
\hline wife_work & $\begin{array}{l}-0.0212 \\
(0.0118)\end{array}$ & $\begin{array}{c}0.0079 \\
(0.0087)\end{array}$ \\
\hline$\hat{\sigma}$ & 0.1504 & 0.1245 \\
\hline$R^{2}$ & 0.0252 & 0.0925 \\
\hline$N$ & 865 & 1319 \\
\hline
\end{tabular}

Corrected standard errors are shown in parentheses. See Table I for variable definition. Equation (1) refers to the sample of domestic helpers with not more than one year in Hong Kong, while equation (2) refers to those with more than one year in Hong Kong.

* Coefficient is statistically different from zero at the $5 \%$ level.

** Coefficient is statistically different from zero at the $1 \%$ level. 
TABLE VIII

Labor Quality and the Wages of Employers

\begin{tabular}{lccc}
\hline & \multicolumn{3}{c}{ Dependent Variables: } \\
Variable & $(1)$ & $(2)$ & $(3)$ \\
constant & duration_0-9 & duration_10 & $C_{1} \hat{\alpha}_{1}$ \\
\hline $\log V$ & -5.3349 & -0.2505 & 7.5126 \\
& $(0.8773)$ & $(0.0835)$ & $(0.0098)$ \\
$\log ($ husband_wage) & $0.2637^{* *}$ & $0.0289^{* *}$ & $0.0029^{* *}$ \\
& $(0.0922)$ & $(0.0089)$ & $(0.0010)$ \\
$\hat{\sigma}$ & $0.5418^{* *}$ & 0.0032 & $0.0038^{* *}$ \\
$R^{2}$ & $(0.0726)$ & $(0.0069)$ & $(0.0008)$ \\
$N$ & 2.3941 & 0.2364 & 0.0279 \\
\hline
\end{tabular}

See Table I for variable definition. Standard errors are corrected for bias due to imputed regressors. Observations where the husband reports no earnings are excluded. The model in column (1) includes only helpers who have less than ten years of residence in Hong Kong. Equation (2) is estimated using a linear probability model.

** Coefficient is statistically different from zero at the $1 \%$ level. 


\section{FIGURE 1}

Frequency Distribution of Domestic Helper Wages
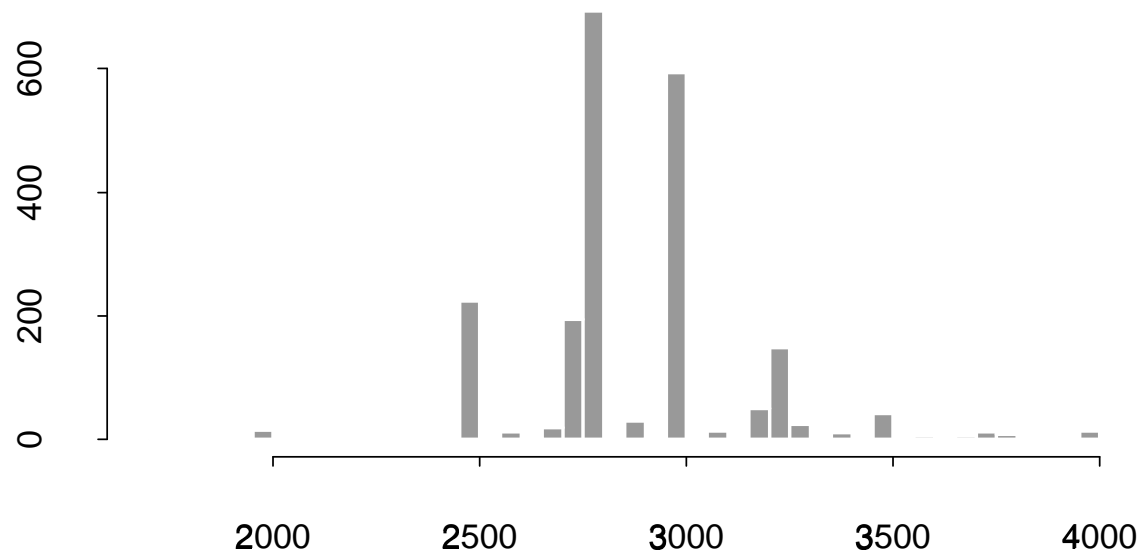

dollars 